\title{
FIRE SUPPRESSION AND ECOSYSTEM CARBON STORAGE
}

\author{
David Tilman,,${ }^{1,7}$ Peter Reich, ${ }^{2}$ Hope Phillips, ${ }^{3}$ Mary Menton, ${ }^{4}$ Ami Patel, 5 \\ Erin Vos, ${ }^{6}$ David Peterson, ${ }^{2}$ And J. KNOPS ${ }^{1}$ \\ ${ }^{1}$ Department of Ecology, Evolution and Behavior, University of Minnesota, \\ 1987 Upper Buford Circle, St. Paul, Minnesota 55108 USA \\ ${ }^{2}$ Department of Forest Resources, University of Minnesota, \\ 1530 N. Cleveland Avenue, St. Paul, Minnesota 55108 USA \\ ${ }^{3}$ College of St. Benedict, Mailbox 1299, 37 S. College Avenue, St. Joseph, Minnesota 56374 USA \\ ${ }^{4} 403$ A West Cameron Avenue, Chapel Hill, North Carolina 27516 USA \\ 5224 Sheldon Avenue, Pittsburgh, Pennsylvania 15220 USA \\ ${ }^{6} 1520$ St. Olaf Avenue, Northfield, Minnesota 55057 USA
}

\begin{abstract}
A 35-year controlled burning experiment in Minnesota oak savanna showed that fire frequency had a great impact on ecosystem carbon (C) stores. Specifically, compared to the historical fire regime, fire suppression led to an average of $1.8 \mathrm{Mg} \cdot \mathrm{ha}^{-1} \cdot \mathrm{yr}^{-1}$ of C storage, with most carbon stored in woody biomass. Forest floor carbon stores were also significantly impacted by fire frequency, but there were no detectable effects of fire suppression on carbon in soil and fine roots combined, or in woody debris. Total ecosystem $\mathrm{C}$ stores averaged $\sim 110 \mathrm{Mg} / \mathrm{ha}$ in stands experiencing presettlement fire frequencies, but $\sim 220 \mathrm{Mg} / \mathrm{ha}$ in stands experiencing fire suppression. If comparable rates of $\mathrm{C}$ storage were to occur in other ecosystems in response to the current extent of fire suppression in the United States, fire suppression in the USA might account for $8-20 \%$ of missing global
\end{abstract} carbon.

Key words: carbon storage; fire suppression; missing carbon; oak savanna.

\section{INTRODUCTION}

Humans have long modified fire frequency (e.g., Pyne 1982, Bird and Cali 1998). During the 1900s fire frequency has increased in parts of the world, especially the tropics, because of the use of fire as a landclearing mechanism (e.g., Sanford et al. 1985, Andreae 1991, Goldammer 1991), and has decreased in other regions, such as the United States, because of active fire suppression (Fig. 1; U.S. Census Bureau 1997). Because the burning of ecosystem biomass creates $\sim 20-25 \%$ of annual anthropogenic $\mathrm{CO}_{2}$ (Andreae 1991, Schimel 1995), modifications of fire frequency may significantly change regional and global $\mathrm{C}$ budgets (e.g., Fahenstock and Agee 1983, Andreae 1991, Stocks 1991, Dixon and Krankina 1993, Dixon et al. 1994, Sohngen and Haynes 1997). However, the longterm impacts of fire frequency on $\mathrm{C}$ balance are complex because fire frequency is one of the variables controlling the species composition and functioning of terrestrial ecosystems. High fire frequencies not only convert some organic $\mathrm{C}$ in ecosystems to $\mathrm{CO}_{2}$, but also

Manuscript received 19 July 1999; revised 21 February 2000; accepted 8 March 2000.

${ }^{7}$ E-mail: tilman@1ter.umn.edu change the abundances and identities of the dominant plant species. A decrease in fire frequency, for instance, was the apparent cause of the creation of the Big Woods, a large area of tallgrass prairie in Minnesota that was converted into hardwood forest (Grimm 1984). Such changes in plant composition, in turn, change the rate and extent of $\mathrm{C}$ storage.

Because fire suppression might lead to a period of C accumulation (Houghton et al. 1999), current fire suppression in the United States (Fig. 1) may be contributing to the apparently high current rate of $\mathrm{C}$ storage in North American ecosystems (e.g., Birdsey et al. 1993, Turner et al. 1995, Fan et al. 1998). Fire suppression could both decrease the rate of release of $\mathrm{CO}_{2}$ caused by burning and increase $\mathrm{C}$ storage in woody biomass, soils, and other compartments in savannas, woodlands, and grasslands being invaded by trees. Even within forests, fire suppression might increase C storage by allowing stands to reach older ages and to accumulate $\mathrm{C}$ in boles, soils, litter, coarse woody debris, and standing dead trees (Sohngen and Haynes 1997).

We experimentally determined the impact of fire frequency on total ecosystem C stores of 19 stands of savanna subject to various frequencies of prescribed 
FIG. 1. Extent of ecosystem burning in the United States (in millions of hectares per year) from 1926 to 1997 , based on data reported for 1926 through 1969 by the U.S. Census Bureau (1997), and for 1970 through 1997, in annual issues of "Wildfire Statistics," U.S. Forest Service, Government Printing Office, Washington, D.C., USA.

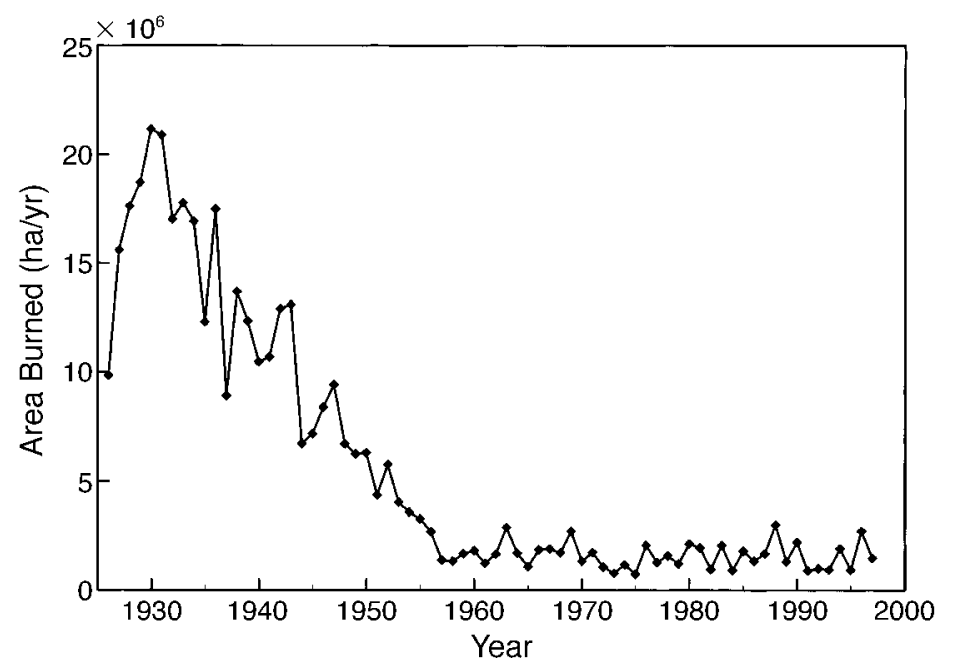

burning for the past 35 years. All stands are located within what had been a large block of oak savanna within Cedar Creek Natural History Area, in central Minnesota. Many midwestern U.S. savannas experience approximately annual to biennial fire (Muir 1913, Stout 1944, Pierce 1954, Peterson 1998). Fire scars on pines bordering the Cedar Creek savanna showed that it experienced approximately annual fires from 1880 to 1910 (Pierce 1954). The savanna had six documented fires from 1910 to 1940 (Pierce 1954), but, except for the prescribed burns described below, has had only one fire since then, in 1955 (Peterson 1998).

\section{Methods}

In 1964 a portion of oak savanna at Cedar Creek was divided into 14 burn compartments ranging in size from 2.5 to 27.5 ha (White 1983, Tester 1989). Five other compartments, consisting of additional unburned or fire-suppression treatments that were adjacent to the initial compartments and part of the original savanna, were added later (Peterson 1998). The prescribed spring burning, begun in 1964 (White 1983), can be viewed as having three fire treatment categories: fire suppression (eight stands experiencing 0,1 , or 2 fires in $35 \mathrm{yr}$ ); moderate fire frequency (four stands experiencing from 4 to 13 fires in $35 \mathrm{yr}$ ); and presettlement fire frequency (seven stands experiencing from 16 to 28 fires in $35 \mathrm{yr}$ ).

We determined total ecosystem $\mathrm{C}$ in the trees of each stand by converting the 1995 diameter at breast height of each tree with $\mathrm{dbh} \geq 5 \mathrm{~cm}$, within a $50 \times 75 \mathrm{~m}$ area in each stand, to $\mathrm{C}$ using allometric relationships for aboveground biomass (Alemdag 1983) and assuming that coarse roots were $17 \%$ of aboveground tree mass (Smith and Brand 1983, Grigal and Ohmann 1992, Brown et al. 1997). We estimated C stored in other ecosystem compartments (soil and fine roots, other vegetation, coarse woody debris, and forest floor) in 1998 by sampling four different $1 \times 4 \mathrm{~m}$ sites uniformly spaced within each stand, and using the average of the four sites as the estimated value for the stand. In particular, we collected all forest floor litter and organic matter (all material with a diameter $<1 \mathrm{~cm}$ ) within a $0.5 \times 1.0 \mathrm{~m}$ portion of each site. We then collected two $5 \mathrm{~cm}$ diameter soil cores (0 to $20 \mathrm{~cm}$ depth) within the portion of a site sampled for forest floor litter. These two soil cores were lumped for analysis of the $\mathrm{C}$ content of mineral soil and fine roots combined. We also collected one $5 \mathrm{~cm}$ diameter soil core from 20 to $100 \mathrm{~cm}$ depth at each site for determination of soil and fine root $\mathrm{C}$. All sampling was done to determine total ecosystem $\mathrm{C}$ without any overlap in sampling. Samples were dried, ground, and analyzed for $\mathrm{C}$ content via loss on ignition (Grigal and Ohmann 1992). Coarse woody debris was estimated in each $1 \times 4 \mathrm{~m}$ site by measuring the diameter and length of each piece of dead wood with a diameter of $1 \mathrm{~cm}$ or more, calculating volume, and converting these to $\mathrm{C}$ based on averaged dry stem densities. To estimate $\mathrm{C}$ in other vegetation, we measured the basal diameters of each shrub or other woody plant with dbh $<5 \mathrm{~cm}$ in a $1 \times 4 \mathrm{~m}$ site and converted these to $\mathrm{C}$ using allometric equations (Smith and Brand 1983). All of this sampling was repeated at each of the four sites within each of the 19 stands. Stand averages were used in analyses, which were performed using SAS 6.12 (SAS Institute 1989) on a Sun Sparc 10 computer. The carbon concentration of all plant biomass and detrital components was assumed to be $47 \%$. Total ecosystem $\mathrm{C}$ for a stand is the sum of $\mathrm{C}$ (on an areal basis) in trees, other vegetation, soil and fine roots, coarse roots, forest floor, and woody debris.

\section{RESUlTS}

Total ecosystem carbon was highly dependent on the fire treatment (Fig. 2). The fire suppression treatment had $90 \%$ more total ecosystem $\mathrm{C}$ than the presettlement (high) fire treatment (Fig. 2) and had 67\% more total $\mathrm{C}$ than the moderate fire treatment. Both differences 


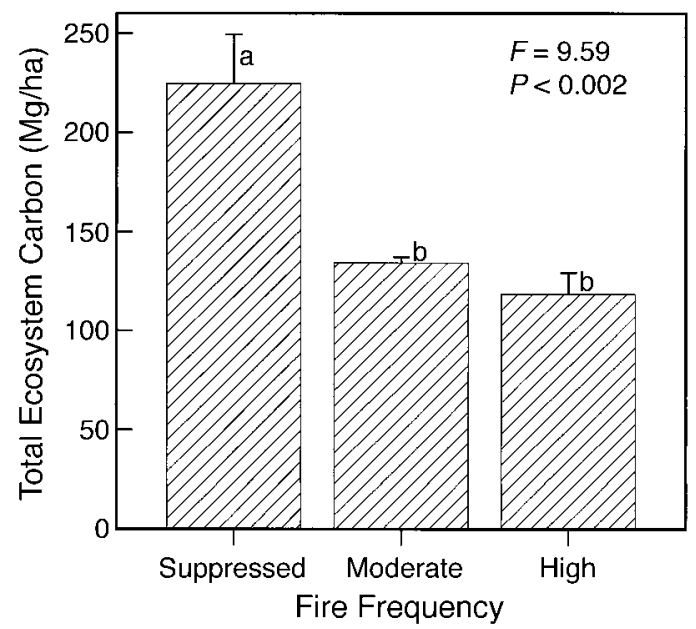

FIG. 2. Total stores of carbon (as mean $\mathrm{C}+1 \mathrm{SE}$ ) in all forms (summed, on an areal basis, for soil plus fine roots, coarse roots, forest floor litter, coarse woody debris, trees, and other vegetation) in the three fire treatments at Cedar Creek Natural History Area. The eight fire-suppressed plots had a mean fire frequency of $0.025 \mathrm{yr}^{-1}$, the four moderate fire frequency plots had a fire frequency of $0.24 \mathrm{yr}^{-1}$, and the seven high fire frequency plots had a mean fire frequency of $0.62 \mathrm{yr}^{-1}$. Results for an ANOVA ( $\left.\mathrm{df}=2,16\right)$ of the effects of the fire frequency treatments on total ecosystem carbon are shown. Means sharing the same lowercase letter do not differ significantly $(P>0.05)$ based on Student-NewmanKeuls multiple comparison test.

were significant $(P<0.05)$, but the moderate and high fire treatments did not differ significantly $(P>0.05)$. Total ecosystem $\mathrm{C}$ decreased approximately linearly with the actual fire frequency $\left(F_{r}\right)$ of the individual stands (linear regression: $\mathrm{C}=208-143 \times F, r=$ $-0.61, N=19, P<0.01 ; \mathrm{C}$ is expressed in units of megagrams per hectare, which are equivalent to metric tons of $\mathrm{C}$ per hectare). The greater total ecosystem $\mathrm{C}$ of the fire suppression treatment was caused mostly by greater aboveground tree biomass (Fig. 3A), and by the associated greater coarse tree roots belowground (Fig. 3B). There were no detectable effects of fire frequency on belowground $\mathrm{C}$ (soil $\mathrm{C}$ plus fine root $\mathrm{C}$ ) at the $0-$ $20 \mathrm{~cm}$ depth (ANOVA $F_{2,16}=0.54, P=0.6$ ) or at the 20-100 cm depth (ANOVA $F_{2,16}=2.0, P=0.2$ ). Belowground $\mathrm{C}$ at $0-20 \mathrm{~cm}$ was lower in suppressed stands $(3740 \mathrm{Mg} / \mathrm{ha})$ than in those with high fire frequency (4170 Mg/ha), and the opposite occurred at 20$100 \mathrm{~cm}$ depth $(6260 \mathrm{Mg} / \mathrm{ha}$ for suppressed and 5280 $\mathrm{Mg} / \mathrm{ha}$ for high fire frequency), but these differences were not significant. Belowground $\mathrm{C}$ for the full depth profile $(0-100 \mathrm{~cm})$, which comprised from $31 \%$ to $92 \%$ of total ecosystem $\mathrm{C}$ ( mean $=64 \%)$, was also not detectably dependent on fire treatment (Fig. 3C). Forest floor $\mathrm{C}$ was highly dependent on fire treatment (Fig. $3 \mathrm{D}$ ), but $\mathrm{C}$ in coarse woody debris was not (Fig. 3E), perhaps because of great spatial heterogeneity in coarse woody debris within sites. Shrub C was highest at moderate fire frequency (Fig. 3F).
Fire suppression led to a shift in the absolute and relative abundances of the two major tree species. The relative abundance of bur oak (Quercus macrocarpa) changed from $28 \%$ of total woody plant biomass at presettlement fire frequencies to $5 \%$ under fire suppression, whereas pin oak (Q. ellipsoidalis) changed from $72 \%$ to $92 \%$ of woody plant biomass when comparing high fire frequency plots with those experiencing fire suppression. The dominant shrub, hazelnut (Corylus americana), reached its peak abundance at moderate fire frequency.

\section{DISCUSSION}

Fire suppression led to a large increase in carbon storage. The fire suppression treatment had an average of $106 \mathrm{Mg} / \mathrm{ha}$ more $\mathrm{C}$ than the presettlement fire treatment. This difference in current $\mathrm{C}$ stores likely resulted from $\mathrm{C}$ accumulation during both the fire frequency experiment (1964 to the present) and the period of fire suppression from 1940 to 1964 . From 1910 to 1940 there was a fire about every 5 years (Pierce 1954), which falls into the moderate fire frequency category, for which our experiment suggests that little $\mathrm{C}$ accumulation would have occurred (Fig. 2). However, the $24 \mathrm{yr}$ of complete fire suppression from 1940 to the start of the experiment likely would have been a time of $\mathrm{C}$ accumulation in all the sites. Although we have no data on the initial $\mathrm{C}$ content of the 19 sites, it seems likely that the ones experiencing high fire frequencies have lost $\mathrm{C}$ and those experiencing fire suppression have gained $C$ since burning began in 1964 . The annual rate of net $\mathrm{C}$ storage caused by fire suppression can be conservatively estimated by attributing the mean difference in stored $\mathrm{C}$ between the high (presettlement) fire treatment and the fire suppression treatment, 106 $\mathrm{Mg} / \mathrm{ha}$ of $\mathrm{C}$, to the full 59-yr period since the last wildfire (1939). This gives a rate of $1.8 \mathrm{Mg} \cdot \mathrm{ha}^{-1} \cdot \mathrm{yr}^{-1}$ of C accumulation caused by fire suppression.

The C storage was mainly caused by increased tree mass following fire suppression. This increase corresponded with a shift from savanna at presettlement fire frequencies to shrub woodland at moderate fire frequencies, to a more closed canopy pin oak forest with fire suppression. Thus, as detailed by Tester (1989) and D. W. Peterson and P. B. Reich (unpublished manuscript), fire suppression changed the species composition of these habitats. The growth and spread of a single species, pin oak, accounts for $1.3 \mathrm{Mg} \cdot \mathrm{ha}^{-1} \cdot \mathrm{yr}^{-1}$ of $\mathrm{C}$ accumulation, $\sim 70 \%$ of the annual rate of accumulation. Although the stands experiencing fire suppression did have somewhat greater $\mathrm{C}$ stores in soil and fine roots (Fig. 3C), we did not detect a significant effect of fire suppression on these stores, and surface soils $(0-20 \mathrm{~cm})$ seemed to respond differently than deeper soils $(20-100 \mathrm{~cm})$. However, given the spatial heterogeneity of these soils, greater sampling of soils within each stand would likely allow better determination of the effects of fire frequency on soil and fine 

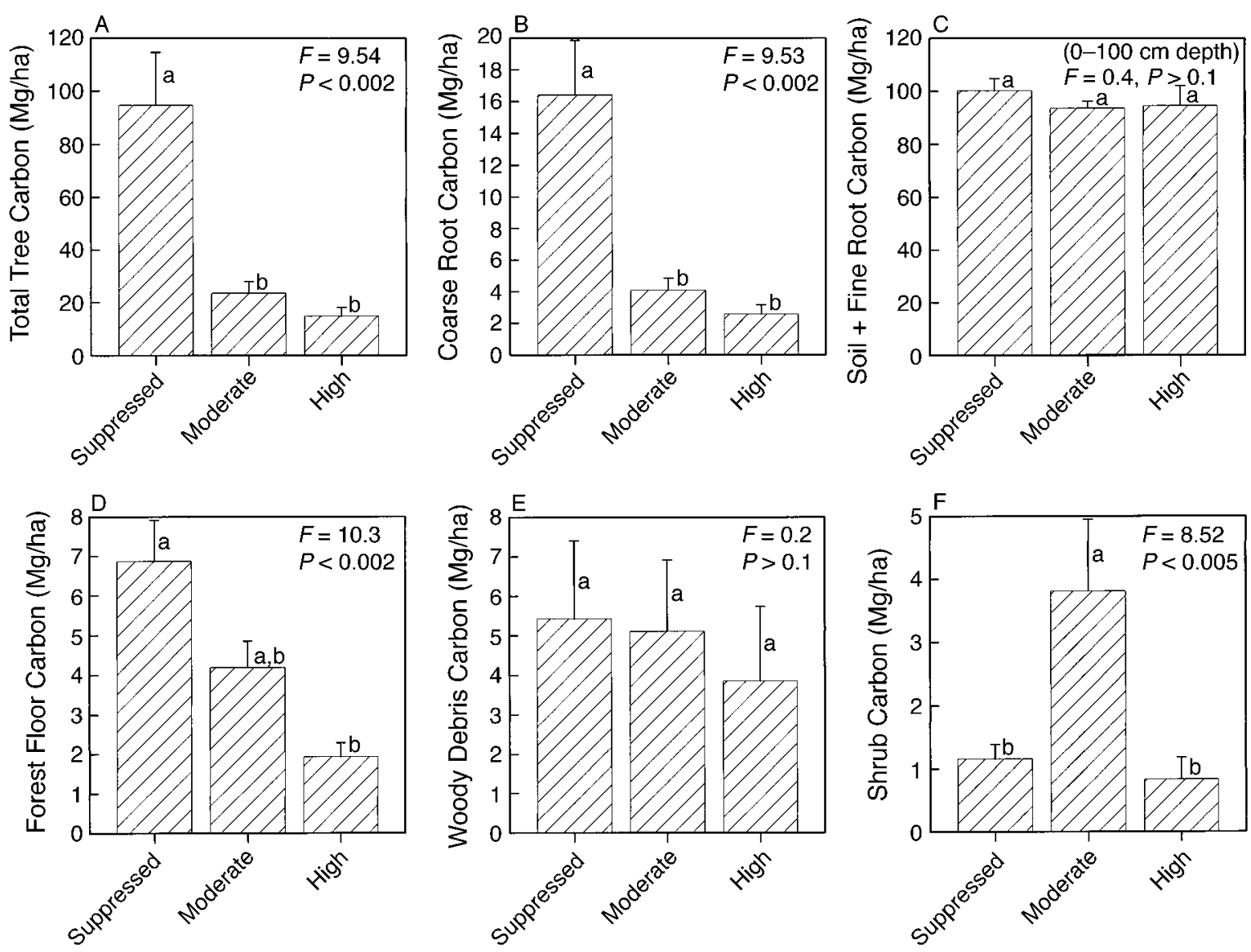

Fire Frequency

FIG. 3. Responses (mean $+1 \mathrm{SE}$ ) of all six carbon store components to fire frequency. Results of an ANOVA (df $=2$, 16) for the dependence of each component on fire frequency are given. Means sharing the same lowercase letter do not differ significantly $(P>0.05)$, based on Student-Newman-Keuls multiple comparison test. Total tree carbon (A), coarse root carbon (B), and forest floor carbon (D) were all significantly greater $(P<0.01)$ in suppressed than in moderate or high fire frequencies. Shrub carbon was greater at moderate fire frequencies. The other components were not significantly dependent on fire frequency $(P>0.1)$.

root carbon, as might a longer time series. Other work shows that fire suppression can cause soil C to increase (Liski et al. 1998, Slaughter et al. 1998, Kurz and Apps 1999).

Our estimated rate of $\mathrm{C}$ storage caused by fire suppression, $1.8 \mathrm{Mg} \cdot \mathrm{ha}^{-1} \cdot \mathrm{yr}^{-1}$, is similar to the average of 1.4 $\mathrm{Mg} \cdot \mathrm{ha}^{-1} \cdot \mathrm{yr}^{-1}$ of $\mathrm{C}$ accumulation reported for live trees in forest ecosystems of the United States (Birdsey 1992). Fire suppression in a Venezuelan savanna led to an increase in C stores comparable to that at Cedar Creek (San Jose et al. 1998), with the rate of storage estimated as $1.4 \mathrm{Mg} \cdot \mathrm{ha}^{-1} \cdot \mathrm{yr}^{-1}$ over the first 25 years after fire suppression, and at $2.8 \mathrm{Mg} \cdot \mathrm{ha}^{-1} \cdot \mathrm{yr}^{-1}$ over a 51-year period of fire suppression (San Jose et al. 1998).

Fires were a common occurrence in many North American ecosystems at the time of European settlement, but fire frequencies have declined dramatically because of barriers to the spread of fire, active fire suppression, and decreased rates of fires of human origin (e.g., Pyne 1982; Fig. 1). Of the $2.95 \times 10^{8}$ ha of U.S. forest (U.S. Forest Service 1988), $1.66 \times 10^{8}$ ha is classified by state foresters as currently experiencing active fire suppression (Bathrick 1993), suggesting that fire suppression has impacted many U.S. ecosystems (e.g., Pyne 1982, Clark 1990). Only detailed regional analyses will be able to determine the quantitative impact of fire suppression on $\mathrm{C}$ storage in the United States, or in other parts of the world in which fire suppression might occur. However, some rough estimates of the magnitude of annual C storage in the United States and in other regions that might be caused by fire suppression can be calculated. For instance, the United States has $\sim 0.5 \times 10^{8}$ ha of savanna/woodland. If our observed rate of fire-suppression-caused annual C storage, $1.8 \mathrm{Mg} \cdot \mathrm{ha}^{-1} \cdot \mathrm{yr}^{-1}$, were to occur in these areas, there would be a $\mathrm{C}$ sink of $\sim 0.1 \times 10^{15} \mathrm{~g} / \mathrm{yr}$ in U.S. savanna/woodland. Because our rate of $\mathrm{C}$ storage 
in savanna is similar to that for growing U.S. forests (e.g., Grigal and Ohmann 1992), an upper bound of the potential contributions of current U.S. fire suppression to $\mathrm{C}$ storage in U.S. forests could be obtained by multiplying the forested area of the U.S. subject to fire suppression, $1.66 \times 10^{8}$ ha, by our observed rate of $\mathrm{C}$ storage. This gives an upper bound of $\sim 0.3 \times 10^{15} \mathrm{~g} /$ yr. Our estimated range of $0.1-0.3 \times 10^{15} \mathrm{~g} / \mathrm{yr}$ of $\mathrm{C}$ storage caused by U.S. fire suppression represents $\sim 8-$ $25 \%$ of total U.S. $\mathrm{CO}_{2}$ emissions and $\sim 7-20 \%$ of the global missing carbon sink (Birdsey et al. 1993). Houghton et al. (1999) estimated various sources of C storage in the United States. The sum of the three that relate to fire suppression (woody encroachment into former grasslands, decreased U.S. wildfire, and fire suppression in western pine woodlands) is $0.24 \times 10^{15}$ $\mathrm{g} / \mathrm{yr}$ of $\mathrm{C}$, which is close to our upper bound. Thus, accumulation of woody biomass caused by fire suppression in the United States may help explain the apparent functioning of North America as a carbon sink (Birdsey et al. 1993, Fan et al. 1998).

Our work supports the proposal that increased fire suppression and decreased anthropogenic burning of vegetation could significantly influence global carbon dynamics (Dixon et al. 1994, Sampson and Clark 1995, Sohngen and Haynes 1997, San Jose et al. 1998). Atmospheric $\mathrm{CO}_{2}$ is currently accumulating at $\sim 3.2 \times$ $10^{15} \mathrm{~g} \mathrm{C} / \mathrm{yr}$ (Schimel 1995). Dixon et al. (1994) calculated that fire management in Russia could lead to long-term C storage of $0.6 \times 10^{15} \mathrm{~g} \mathrm{C/yr}$. San Jose et al. (1998) calculated that fire suppression, by causing the transformation of the $2.8 \times 10^{7}$ ha Venezuelan Orinoco Llanos from grassland to semideciduous forest, could lead to a $\mathrm{C}$ sink of $0.08 \times 10^{15} \mathrm{~g} \mathrm{C} / \mathrm{yr}$. Moreover, the immense global extent of tropical savanna and woodland, $2.45 \times 10^{9}$ ha (Schlesinger 1997), suggests that even moderate fire suppression in this ecosystem type could provide a globally significant $\mathrm{C}$ sink. If, for instance, it were possible to suppress fire in $20 \%$ of such habitats, and if this were to lead to storage of 1.4 $\mathrm{Mg} \cdot \mathrm{ha}^{-1} \cdot \mathrm{yr}^{-1}$ (the lower estimate of San Jose et al. [1998] for tropical savanna), this would create a C sink of $0.7 \times 10^{15} \mathrm{~g} / \mathrm{yr}$. Thus, additional fire suppression in Russia and tropical savanna/woodland might conceivably decrease the rate of accumulation of atmospheric $\mathrm{CO}_{2}$ by $1.3 \times 10^{15} \mathrm{~g} \mathrm{C} / \mathrm{yr}$, which would be a $40 \%$ reduction.

There are, however, several significant problems with fire suppression. First, the estimated rates of $\mathrm{C}$ storage that might result from fire suppression are not sustainable in the long term. For instance, Grigal and Ohmann (1992) found that $90 \%$ of total C storage in forests of the Great Lakes region had occurred by 60 years after disturbance. Although this does not include the much slower potential storage of $\mathrm{C}$ in soils following long-term fire suppression (Liski et al. 1998), it seems likely that the $\mathrm{C}$ storage following fire suppression would be approximately a logistic function of time, with most storage occurring during the period of rapid tree biomass accumulation. This suggests that much of the potential for C storage in the United States via fire suppression may have already occurred, because it has already been 50-60 years after the major reduction in U.S. fire frequency (Fig. 1). Second, some of the increased $\mathrm{C}$ stores associated with fire suppression represents an accumulation of fuel that might lead to catastrophic, stand-destroying fires, especially during droughts. Depending on the frequency, severity, and extent of such fires, this would decrease the magnitude of $\mathrm{C}$ storage that could result from fire suppression. For instance, Kurz and Apps (1999) found that a marked increase in fire during the 1980s caused a reduction in $\mathrm{C}$ storage in Canadian forests. Third, it is unclear how global climate change might interact with fire frequency to impact $\mathrm{C}$ storage. Although global climate change, by itself, might increase global $\mathrm{C}$ storage via expansion of forested lands (e.g., Smith et al. 1992), climate change may also increase fire frequency (e.g., Beer and Williams 1995, Goldammer and Price 1998), which could counteract this effect. Fourth, fire suppression can have negative impacts via its effects on the diversity, composition, and functioning of savanna and forested ecosystems (e.g., Clark 1990). Thus, although fire suppression has the potential to significantly impact global C dynamics, further research is needed to determine the long-term net effects of fire suppression.

\section{ACKNOWLEDGMENTS}

We thank Joe Fargione, Troy Mielke, Louise Johnson, David Bosanko, and Nancy Larson for their assistance, and Joseph Yavitt and two anonymous reviewers for their comments. This work was supported by National Science Foundation Grant 9411972 and by the Andrew Mellon Foundation.

\section{Literature Cited}

Alemdag, I. S. 1983. Total tree and merchantable stem biomass equations for Ontario hardwoods. Canadian Forestry Service, Petawawa National Forestry Institute, Information Report PI-X-46.

Andreae, M. O. 1991. Biomass burning: its history, use, and distribution and its impact on environmental quality and global climate. Pages 3-21 in J. S. Levine, editor. Global biomass burning: atmospheric, climatic, and biospheric implications. MIT Press, Cambridge, Massachusetts, USA.

Bathrick, R. H. 1993. National association of state foresters 1993 report. State Forestry Statistics Committee, New York, New York, USA.

Beer, T., and A. Williams. 1995. Estimating Australian forest fire danger under conditions of doubled carbon dioxide concentrations. Climatic Change 29:169-188.

Bird, M., and J. Cali. 1998. A million-year record of fire in sub-Saharan Africa. Nature 394:767-769.

Birdsey, R. A. 1992. Carbon storage and accumulation in United States forest ecosystems. U.S. Forest Service General Technical Report WO-59.

Birdsey, R. A., A. J. Plantinga, and L. S. Heath. 1993. Past and prospective carbon storage in United States forests. Forest Ecology and Management 58:33-40.

Brown, S., P. Schroeder, and R. Birdsey. 1997. Aboveground biomass distribution of US eastern hardwood forests and 
the use of large trees as an indicator of forest development. Forest Ecology and Management 96:37-47.

Clark, J. S. 1990. Twentieth-century climate change, fire suppression, and forest production and decomposition in northwestern Minnesota. Canadian Journal of Forest Research 20:219-232.

Dixon, R. K., S. Brown, R. A. Houghton, A. M. Solomon, M. C. Trexler, and J. Wisniewski. 1994. Carbon pools and flux of global forest ecosystems. Science 263:185-190.

Dixon, R. K., and O. N. Krankina. 1993. Forest fires in Russia: carbon dioxide emissions to the atmosphere. Canadian Journal of Forest Research 23:700-705.

Fahenstock, G. R., and J. K. Agee. 1983. Biomass consumption and smoke production by prehistoric and modern forest fires in western Washington. Journal of Forestry 81: 653-657.

Fan, S., M. Gloor, J. Mahlman, S. Pacala, J. Sarmiento, T. Takahashi, and P. Tans. 1998. A large terrestrial carbon sink in North America implied by atmospheric and oceanic carbon dioxide data and models. Science 282:442-446.

Goldammer, J. G. 1991. Tropical wild-land fires and global changes: prehistoric evidence, present fire regimes, and future trends. Pages 83-91 in J. S. Levine, editor. Global biomass burning: atmospheric, climatic, and biospheric implications. MIT Press, Cambridge, Massachusetts, USA.

Goldammer, J. G., and C. Price. 1998. Potential impacts of climate change on fire regimes in the tropics based on MAGICC and a GISS GCM-derived lightning model. Climatic Change 39:273-296.

Grigal, D. F., and L. F. Ohmann. 1992. Carbon storage in upland forests of the Lake States. Soil Science Society of America Journal 56:935-943.

Grimm, E. C. 1984. Fire and other factors controlling the big woods vegetation of Minnesota in the mid-nineteenth century. Ecological Monographs 54:291-311.

Houghton, R. A., J. L. Hackler, and K. T. Lawrence. 1999. The U.S. carbon budget: contributions from land-use change. Science 285:574-579.

Kurz, W. A., and M. J. Apps. 1999. A 70-year retrospective analysis of carbon fluxes in the Canadian forest sector. Ecological Applications 9:526-547.

Liski, J., H. Ilvesniemi, A. Makela, and M. Starr. 1998. Model analysis of the effects of soil age, fires and harvesting on the carbon stores of boreal forest soils. European Journal of Soil Science 49:407-416.

Muir, J. 1913. The story of my boyhood and youth. Houghton Mifflin, New York, New York, USA.

Peterson, D. W. 1998. Fire effects on oak savanna and woodland vegetation in Minnesota. Dissertation. University of Minnesota, St. Paul, Minnesota, USA.

Pierce, R. L. 1954. Vegetation cover types and land use history of the Cedar Creek Natural History Reservation, Anoka and Isanti Counties, Minnesota. Thesis. University of Minnesota, St. Paul, Minnesota, USA.

Pyne, S. J. 1982. Fire in America: a cultural history of wild- land and rural fire. Princeton University Press, Princeton, New Jersey, USA.

Sampson, R. N., and L. R. Clark. 1995. Wildfire and carbon emissions: a policy modeling approach. The Forest Policy Center, Washington, D.C., USA.

Sanford, R. L., Jr., J. Saldarriaga, K. E. Clark, C. Uhl, and R. Herrera. 1985. Amazon rain-forest fires. Science 227: $53-55$.

San Jose, J., R. Montes, and M. Farinas. 1998. Carbon stocks and fluxes in a deciduous scaling from a savanna to a semideciduous forest. Forest Ecology and Management 105: 251-262.

SAS Institute. 1989. SAS/STAT user's guide, Version 6.12. SAS Institute, Cary, North Carolina, USA.

Schimel, D. S. 1995. Terrestrial ecosystems and the carbon cycle. Global Change Biology 1:77-91.

Schlesinger, W. H. 1997. Biogeochemistry: an analysis of global change. Academic Press, San Diego, California, USA.

Slaughter, K. W., D. F. Grigal, and L. F. Ohmann. 1998. Carbon storage in southern boreal forests following fire. Scandinavian Journal of Forest Research 13:119-127.

Smith, T. M., R. Leemans, and H. H. Shugart. 1992. Sensitivity of terrestrial carbon storage to $\mathrm{CO}_{2}$-induced climate change: comparison of four scenarios based on general circulation models. Climatic Change 21:367-384.

Smith, W. B., and G. J. Brand. 1983. Allometric biomass equations for 98 species of herbs, shrubs, and small trees. U.S. Forest Service North Central Forest Experiment Station Research Note NC-299.

Sohngen, B. L., and R. W. Haynes. 1997. The potential for increasing carbon storage in United States unreserved timberlands by reducing forest fire frequency: an economic and ecological analysis. Climatic Change 35:179-197.

Stocks, B. J. 1991. The extent and impact of forest fires in northern circumpolar countries. Pages 197-202 in J. S. Levine, editor. Global biomass burning: atmospheric, climatic, and biospheric implications. MIT Press, Cambridge, Massachusetts, USA.

Stout, A. B. 1944. The bur oak openings in southern Wisconsin. Transactions of the Wisconsin Academy of Science, Arts and Letters 36:141-161.

Tester, J. R. 1989. Effects of fire frequency on oak savanna in east central Minnesota. Bulletin of the Torrey Botanical Club 116:134-144.

Turner, D. P., G. J. Koerper, M. E. Harmon, and J. L. Lee 1995. A carbon budget for forests of the coterminous United States. Ecological Applications 5:421-436.

U.S. Census Bureau. 1997. Historical statistics of the United States. CD-ROM. Cambridge University Press, New York, USA.

U.S. Forest Service. 1988. U.S. forest facts. PA-1384-M U.S. Department of Agriculture, Forest Service, Washington, D.C., USA.

White, A. S. 1983. The effects of thirteen years of annual prescribed burning on a Quercus ellipsoidalis community in Minnesota. Ecology 64:1081-1085.

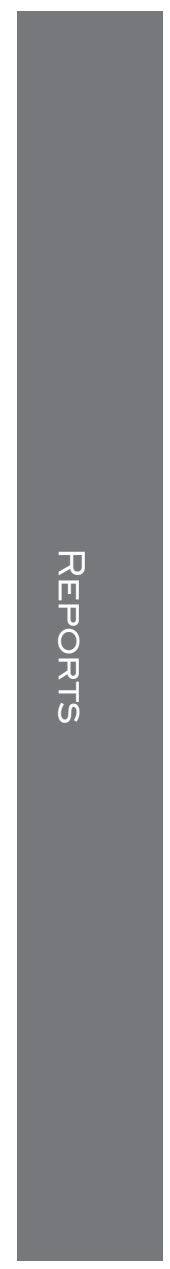

